should not expel or deport aliens solely on the grounds of indigency or becoming public charges. The resolution recommended governments to accord to aliens lawfully in their territory the same measures of public assistance as are accorded to their own nationals and to give effect to the principles enunciated in the Secretary-General's report in any legislation or administrative action required. The Department of Social Affairs of the United Nations has now issued a pamphlet entitled "Study on Assistance to Indigent Aliens" (pp. 81. New York: United Nations. London: H.M.S.O., 1952. 50 cents or $3 s .9 d$.), and this publication embodies the analysis and conclusions contained in the Secretary-General's report as well as some current data and information. Besides the general conclusions drawn from the survey, which led to the resolution already quoted, those reached by the Social Commission and the Economic and Social Council are also indicated. Appended are the texts of some existing conventions or agreements, including the Model Convention on Assistance to Indigent Aliens approved by the Council of the League of Nations in May 1938, the Convention which was concluded between Denmark, Finland, Iceland, Norway and Sweden in January 1951, and that on the Status of Refugees adopted by a United Nations conference on July 25, 1951.

\section{Survey of Physiology in the United States}

The American Physiological Society, under contract by the National Science Foundation, is undertaking a study to determine the present status in the United States of research and education in physiology, including an inventory of available scientific workers, facilities, and institutional and communication problems, and an appraisal of how progress in physiological research relates to other scientific fields and the national welfare. The project has been sponsored by the Foundation, partly because of the central importance of physiological research to all sciences, but primarily to test the value of such a survey-inventory in assisting the Foundation in developing a national policy for science and research in the United States. The contract will be administered for the Foundation by Mr. John Field, assistant director for biological sciences. The survey-inventory will be conducted in two parts, the first being a pilot study, which has already begun and is expected to last for seven to nine months, and from this will be developed the pattern for a more detailed full-scale investigation, which, it is anticipated, will last for an additional eighteen months. The full-scale study will include such problems as the historic development of physiology as a science, present conditions and trends, rescarch and educational facilities and personnel, and the policy for the dissemination of information, communication and publication in physiological work. The pilot phase of the study, costing 33,500 dollars, is under the direction of an honorary central committee, appointed by the American Physiological Society, and the committee has appointed Dr. Orr $\mathrm{E}$. Reynolds, on leave of absence from the Office of Naval Research, to serve as executive director on the pilot project.

\section{Moving a Factory}

Mr. RoY LEwIS, joint author of the recently published highly successful book "The English Middle Classes", has written a fascinating account of the resettlement of a factory and its workers in the first of Britain's new towns. The factory, Sunvic Controls,
Ltd., was formerly housed in a "warren of workshops" in Long Acre, Covent Garden, and was rapidly developing the highly skilled business of producing instruments for temperature, electrical and other forms of control. With the rearmament programme, expansion of facilities became essential and urgent in the nation's interest. A new factory was needed; but it was essential to keep at least a nucleus of the skilled staff together. In Harlow new town the requirements were ideally met; the Development Corporation was glad to get a rapidly developing business for its industrial estate. The directors of Sunvic wished to move the whole factory from Long Acre to Harlow, and put the proposition to the staff. Despite many obstacles about 70 per cent of them elected to move and, in his booklet, Lewis describes how these and unexpected difficulties were overcome, how personal problems were resolved and a new team spirit at Harlow was created. The booklet, which may be obtained from Sunvic Controls, Ltd., No. I Factory, Harlow, Essex, admirably describes a sociological experiment which is of the greatest significance in the re-distribution of urban populations from over-crowded cities.

\section{Aslib : Report for 1951}

'I'He annual report of the work of Aslib for the year ended December 31, 1951 (pp. 22 ; London: Aslib, 1952), records an increase in membership from 1,038 in 1950 to 1,219 , the largest percentage increase--. thirty-being in the industrial and commercial membership. Besides the annual conference at Ashorne Hill in October, for which many applicants had to be refused, a successful conference was arranged by the Scottish Branch in May, and one arranged by the Northern Branch at Birmingham in June led to the inauguration of a Midlands Branch in September. The Northern Branch also arranged a successful meeting at Leicester, and six London meetings were held during the year. A number of special groups were also established during the year, covering aeronautical engineering, textiles, economics, and food and agriculture. The report includes an extended analysis of the work of the Information Bureau and Library, which handled 3,521 inquiries during the year, an increase of 33 per cent on 1950 , apart from 1,236 loans from the Aslib library. Of these inquiries, 1,255 were requests for inter-library loans ; and, of the 1,690 telephone inquiries, 464 were for complete bibliographical references of published works and 379 for locations, not necessarily for loans. Of 576 postal inquiries, the most numerous were for complete bibliographical references of published works or references on a specific subject (129 each) and for special library routines, training, ete. (106). By the end of the year, 3,500 translations had been recorded in the index of unpublished translations.

\section{Petroleum Consumption and Refinery Production in Great Britain during 1951}

THE Petroleum Information Bureau (on behalf of the United Kingdom Petroleum Industry Advisory Committee) has released statistics of oil consumption and refinery production in Great Britain during 1951, which show an increase in total consumption of all products of $1,611,137$ tons above that of the previous year. When it comes to output of finished products from the refineries, the figures are even more impressive : $16,430,025$ tons in 1951 , as against $9,283,752$ tons in 1950 . 'This actually reveals the intensive development of refinery capacity which has 